\author{
Research Article
}

\title{
A COMPARATIVE STUDY TO EVALUATE THE EFFECT OF BALA AND SHATAVARI SIDDHA KSHEERA SHIRODHARA AND TILA TAILA SHIRODHARA IN ANIDRA (INSOMNIA)
}

\section{Rani Pooja1*, Wetal.R.Vishakha², Gupta Arun³ \\ *1Panchakarma Vaidya, All India Institute of Ayurveda, Gautam Puri, Sarita Viahar, New Delhi. \\ ${ }^{2}$ Associate Professor, ${ }^{3}$ Professor \& HOD, Department of Panchakarma, Ch. Brahm Prakash Ayurved Charak Sansthan, Khera Dabar, Najafgarh, New Delhi.}

\begin{tabular}{l} 
Article info \\
Article History: \\
Received: 01-12-2021 \\
Revised: 20-12-2021 \\
Accepted: 02-01-2022 \\
\hline KEYWORDS: \\
Shirodhara, \\
Insomnia, Anidra, \\
Bala, Shatavari \\
Siddha Ksheera \\
Shirodhara, Tila \\
Taila.
\end{tabular}

\section{INTRODUCTION}

Anidra (Insomnia) means "na nidra abhavarthe" i.e., deprivation of sleep or disturbed sleep[1]. According to Charak "As proper Aahar is required for maintenance of health similarly adequate Nidra is required for Sukha and Aarogya, hence included under Tryaupasthambha (three basic supports of life) [2]. Acharya Charak, Sushruta and Vagbhatta have mentioned six, three and seven types of Nidra respectively. Out of them one is Vaikariki Nidra which can be correlated with sleep disorders occurring due to decrease in Kapha dosha or due to any unpleasant condition in the body and mind ${ }^{[3]}$.

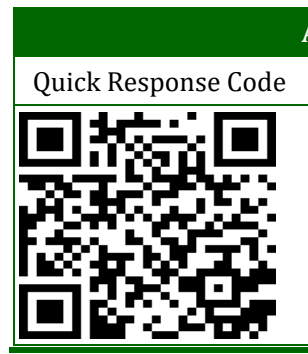

https://doi.org/10.47070/ijapr.v9i12.2205

Published by Mahadev Publications (Regd.) publication licensed under a Creative Commons Attribution-NonCommercialShareAlike 4.0 International (CC BY-NC-SA 4.0)
There are various causative factors responsible for Anidra among them physical causative factors include dietary articles which possessing dry and rough properties, excessive physical exertion, exercise, fasting, indulgence in sexual intercourse, inadequate administration of Panchakarma therapies like Vamana (emesis), Virechana (purgation), Nasya (nasal medications), Raktamokshana (bloodletting), and Dhooma (medicated smoke). Psychological causes include fear, anxiety, anger, ecstatic state, sorrow, greed, and agitation[5]. Inadequate sleep causes Jrimbha (yawning), Angamarda (body ache), Tandra (drowsiness), Shiroroga (head disorders), Shira and Akshi gaurav (heaviness in eyes and head), Aalasya (laziness), Bhrama (giddiness), Apaka (indigestion), Moha (stupor) and Vatajanya rogas ${ }^{[6]}$. As per classic pathogenesis of Anidra involves Vata and Pitta Dosha mainly. The reported prevalence of insomnia is $9 \%$ in the general population and about 30\% suffer from 
occasional insomnia[8]. It has been found that disturbed sleep or less sleep can lead to various medical conditions includes stroke, obesity, diabetes, hypertension and psychological problems etc. Treatment approach for insomnia in modern medicines includes hypnotics and sedatives which cause drug dependency and leads to ill-effects on health. In Ayurveda for the treatment of Anidra, Shirodhara (Oil dripping) procedure with different liquid media has been mentioned. Keeping all these points this study has been designed to evaluate the effect of Shirodhara with Bala and Shatavari Siddha Ksheera and Tila oil. The main aim of this study is to • compare the effect of Shirodhara therapy between Bala and Shatavari Siddha Ksheera and Tila tail in Anidra. Also, to find out whether change in drugs or liquid media plays role in effect of the therapy.

\section{Materials and Methods}

Research design: The study was a randomized, parallel group comparative design clinical study.

\section{Ethical Clearance}

Before starting the clinical trial on patients of Anidra (Insomnia) ethical clearance was taken from the Institutional Ethical Committee (IEC) of Ch. Brahm Prakash Ayurveda Charak Sansthan, Khera Dabar, Najafgarh, New Delhi. Trial no.F1(533)/13/CBPACS/ Admin/IEC/6710 dated 3.01.2019.

\section{CTRI Registration}

CTRI Reg. No. was obtained CTRI/2019/03/018093 dated 14.03.2019.

\section{Collection and identification of Drugs}

The ingredients Bala and Shatavari and Til Oil were procured from authentic distributors drugs were identified in the Department of Dravyaguna CBPACS, Delhi.

\section{Preparation of Drugs for Shirodhara}

For Bala and Shatavari Siddha Ksheera dhara take Bala and Shatavari moola each 48 grams in quantity. Then $6000 \mathrm{ml}$ of water boiled till it reduces to half of its quantity. Further add $1500 \mathrm{ml}$ of milk in it and boiled it till the quantity get reduced to $1500 \mathrm{ml}$. After that filter it with the piece of cloth and use it for Khseera dhara purpose. Tila Oil was after identification and authentication directly used for the procedure.

\section{Inclusion Criteria}

1. Patients of chronic insomnia (Anidra) i.e. (at least three nights a week for a month or longer) [10].

2. Age group 16 to 50 years.

Table 1: Ayurvedic Scoring adopted for Anidra[11]
3. Patients of insomnia with hypertension, depression and anxiety disorders without complications of any other systematic diseases.

\section{Exclusion Criteria}

1. Having major psychiatric illness like schizophrenia, Alzheimer's etc.

2. With alcohol dependency.

3. Patients of asthma, malignancies, liver cirrhosis, chronic renal failure.

4. Patients of any acute illness.

\section{Sampling Method}

Lottery method random numbers were utilized for the study.

\section{Selection of patient}

Patients of Anidra were selected from OPD and IPD of Ch. Brahm Prakash Ayurveda Charak Sansthan, New Delhi. Consort guidelines were followed for the reporting of the study.

Total 131 patients diagnosed as Anidra (Insomnia) as per ICD -10 criteria were selected from Outpatient and in-patient in the department of Panchakarma from Ch. Brahm Prakash Ayurveda Charak Sansthan, New Delhi. India

\section{Intervention}

All the patients were randomly divided into two groups: group A and group B.

Group A (66) received Bala and Shatavari Siddha Ksheera Shirodhara.

Group B (60) received Tila Taila Shirodhara

Both groups received their respective interventions in morning after having light breakfast.

\section{Duration of intervention}

14 days which includes Shirodhara for 07 days and follow-up on $14^{\text {th }}$ day.

\section{Consent of patients}

The nature and design of the study were explained to patients, and informed consent was obtained. During the study, patients were asked to adhere to the treatment protocol and report any adverse events to the investigators at the earliest.

\section{Criteria of Assessment:}

All Ayurvedic parameters and Assessment scale was calculated at base line. The sample size was 63 in each group under $5 \%$ alpha error and $90 \%$ power of test. All the patients were assessed for relief in sign and symptoms after the completion of trial.

For subjective parameters grading/scoring pattern was adopted as follows-

\begin{tabular}{|c|l|l|}
\hline S.no. & Parameters & Grade \\
\hline 1. & Sleeplessness & \\
\hline 1. & No sleeplessness & 0 \\
\hline
\end{tabular}




\begin{tabular}{|c|l|l|}
\hline 2. & Occasionally & 1 \\
\hline 3. & Mild & 2 \\
\hline 4. & Moderate & 3 \\
\hline 5. & Severe, require medicine & 4 \\
\hline 2. & Headache & \\
\hline 1. & No headache & 0 \\
\hline 2. & Occasionally & 1 \\
\hline 3. & Mild & 2 \\
\hline 4. & Moderate & 3 \\
\hline 5. & Severe, require medicine & 4 \\
\hline 3. & Heaviness & \\
\hline 1. & No heaviness & 0 \\
\hline 2. & Occasionally & 1 \\
\hline 3. & Mild & 2 \\
\hline 4. & Moderate & 3 \\
\hline 5. & Severe, require medicine & 4 \\
\hline
\end{tabular}

Table 2: Insomnia Severity Index Scale ${ }^{[12]}$

\begin{tabular}{|c|c|c|}
\hline S. No. & Questionnaire & Score \\
\hline 1. & Difficulty falling asleep (it takes you to fall asleep after turning-off the lights) & \\
\hline i) & None & 0 \\
\hline ii) & Ayurveds & 1 \\
\hline iii) & (4) & 2 \\
\hline iv) & 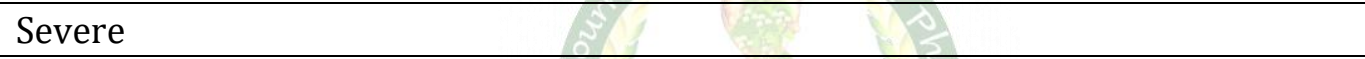 & 3 \\
\hline v) & 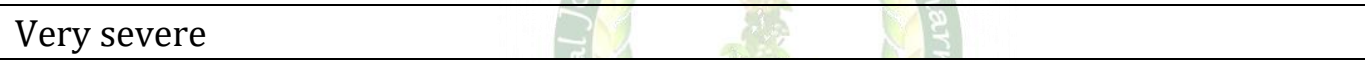 & 4 \\
\hline 2. & Difficulty staying asleep & \\
\hline i) & None & 0 \\
\hline ii) & 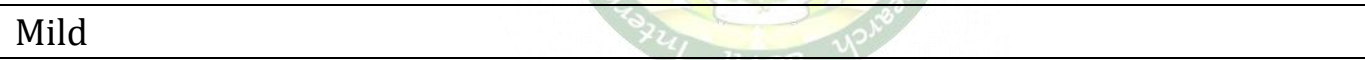 & 1 \\
\hline iii) & Moderate & 2 \\
\hline iv) & Severe & 3 \\
\hline v) & Very severe & 4 \\
\hline 3. & Problem waking up too early & \\
\hline i) & None & 0 \\
\hline ii) & Mild & 1 \\
\hline iii) & Moderate & 2 \\
\hline iv) & Severe & 3 \\
\hline v) & Very severe & 4 \\
\hline 4. & How satisfied/dissatisfied are you with your current sleep pattern? & \\
\hline i) & Very Satisfied & 0 \\
\hline ii) & Satisfied & 1 \\
\hline iii) & Moderately Satisfied & 2 \\
\hline iv) & Dissatisfied & 3 \\
\hline v) & Very Dissatisfied & 4 \\
\hline 5. & $\begin{array}{l}\text { How noticeable to others do you think your sleep problem is in terms of } \\
\text { impairing the quality of your life? }\end{array}$ & \\
\hline i) & Not at all noticeable & 0 \\
\hline ii) & A Little & 1 \\
\hline iii) & Somewhat & 2 \\
\hline iv) & Much & 3 \\
\hline
\end{tabular}


Int. J. Ayur. Pharma Research, 2021;9(12):1-10

\begin{tabular}{|c|l|c|}
\hline v) & Very Much Noticeable & 4 \\
\hline 6. & How worried/distressed are you about your current sleep problem? & \\
\hline i) & Not at all noticeable & 0 \\
\hline ii) & A Little & 1 \\
\hline iii) & Somewhat & 2 \\
\hline iv) & Much & 3 \\
\hline v) & Very Much Noticeable & 4 \\
\hline 7. & $\begin{array}{l}\text { To what extent do you consider your sleep problem to interfere with your daily } \\
\text { functioning (e.g. daytime fatigue, mood, ability to function at work/ daily chores, }\end{array}$ & \\
\hline i) & Noncentration, memory, mood, etc.) currently? & 0 \\
\hline ii) & A Little & 1 \\
\hline iii) & Somewhat & 2 \\
\hline iv) & Much & 3 \\
\hline v) & Very much interfering & 4 \\
\hline
\end{tabular}

Total score categories: $0-7=$ No clinically significant insomnia, 8-14 $=$ Sub threshold insomnia, $15-21=$ Clinical insomnia (moderate severity), 22-28 = Clinical insomnia (severe).

\section{Statistical analysis}

Statistical analysis of the collected data was done. It was analyzed in terms of mean Score (x) Standard Deviation (S.D.), Standard Error (S.E.). For intra-group comparison Paired Student ' $t$ ' test was carried out and for inter-group comparison unpaired ' $\mathrm{t}$ ' test was carried out at a level of $0.05,0.02,0.01,0.001$ of ' $P$ ' value. Paired and unpaired student ' $\mathrm{t}$ ' test was done using in built Microsoft software data analysis pack 2010.

Results

In this study total 131 patients were enrolled out of which there were total 05 dropouts. In Group A 03 and in Group 02. So, there were 66 patients in Group A and 60 in Group B.

Table 3: Patient Demographic data

\begin{tabular}{|c|c|c|c|c|}
\hline S. No. & Patient Profile & $\sqrt{x+3}$ & No. of Patients & Percentage \% \\
\hline \multirow[t]{2}{*}{1.} & \multirow[t]{2}{*}{ Gender } & Male & 29 & 23 \\
\hline & & Female & 97 & 77 \\
\hline \multirow[t]{4}{*}{2.} & \multirow[t]{4}{*}{ Age } & $16-25$ & 55 & 43.6 \\
\hline & & $26-35$ & 27 & 21.4 \\
\hline & & $36-45$ & 30 & 23.8 \\
\hline & & $46-50$ & 14 & 11.1 \\
\hline \multirow[t]{4}{*}{3.} & \multirow[t]{4}{*}{ Educational Status } & Illiterate & 4 & 3 \\
\hline & & Primary & 3 & 2 \\
\hline & & Metric & 21 & 16 \\
\hline & & Post-metric & 98 & 89 \\
\hline \multirow[t]{4}{*}{4.} & \multirow[t]{4}{*}{ Occupational Status } & Student & 51 & 40 \\
\hline & & Housewife & 45 & 36 \\
\hline & & Service & 28 & 22 \\
\hline & & Labor & 2 & 1 \\
\hline \multirow[t]{2}{*}{5.} & \multirow[t]{2}{*}{ Diet } & Vegetarian & 58 & 46 \\
\hline & & Mixed & 68 & 54 \\
\hline \multirow[t]{3}{*}{6.} & \multirow[t]{3}{*}{ Sharirika Prakriti } & Vata-pitta & 35 & 27 \\
\hline & & Pitta-Kapha & 37 & 29 \\
\hline & & Vata-kapha & 54 & 43 \\
\hline \multirow[t]{2}{*}{7.} & \multirow[t]{2}{*}{ Mansika Prakriti } & Rajsika & 80 & 63 \\
\hline & & Tamsika & 46 & 37 \\
\hline 8. & Koshtha & Krura & 34 & 27 \\
\hline
\end{tabular}




\begin{tabular}{|c|c|c|c|c|}
\hline & & Mridu & 21 & 17 \\
\hline & & Madhyam & 71 & 56 \\
\hline \multirow[t]{4}{*}{9.} & \multirow[t]{4}{*}{ Agni (Digestive Fire) } & Vishama & 54 & 43 \\
\hline & & Tikshna & 41 & 32 \\
\hline & & Manda & 26 & 21 \\
\hline & & Sama & 5 & 4 \\
\hline \multirow[t]{2}{*}{10.} & \multirow{2}{*}{$\begin{array}{l}\text { Mala (Bowel } \\
\text { Movement) }\end{array}$} & Clear & 98 & 77 \\
\hline & & Constipated & 28 & 13 \\
\hline \multirow[t]{6}{*}{11.} & \multirow[t]{6}{*}{ Nidana (Cause) } & Excess Anxiety & 56 & 44 \\
\hline & & Family disputes & 41 & 33 \\
\hline & & Financial Issues & 6 & 5 \\
\hline & & $\begin{array}{l}\text { Loss of family } \\
\text { members }\end{array}$ & 6 & 5 \\
\hline & & Social Phobia & 4 & 3 \\
\hline & & $\begin{array}{l}\text { Menopausal } \\
\text { Issues }\end{array}$ & 1 & 1 \\
\hline
\end{tabular}

Table 4: Intra group comparison between Group A and Group B (After treatment)

\begin{tabular}{|c|c|c|c|c|c|c|c|c|c|c|}
\hline \multirow[t]{2}{*}{ Parameters } & \multirow[t]{2}{*}{ Group } & \multirow[t]{2}{*}{$\mathbf{N}$} & \multicolumn{3}{|c|}{ Mean } & \multirow{2}{*}{$\begin{array}{l}\text { \% of } \\
\text { Relief }\end{array}$} & \multirow{2}{*}{$\begin{array}{l}\text { SD } \\
( \pm)\end{array}$} & \multirow{2}{*}{$\begin{array}{l}\text { SE } \\
( \pm)\end{array}$} & \multirow[t]{2}{*}{$\mathbf{T}$} & \multirow[t]{2}{*}{$\mathbf{P}$} \\
\hline & & & BT & AT & DIF & & & & & \\
\hline \multirow[t]{2}{*}{ Sleeplessness } & A & 66 & 3.12 & 0.75 & 2.36 & 75.72 & 0.51 & 0.06 & 37.2 & $<0.001$ \\
\hline & B & 60 & 3.11 & 0.88 & 2.23 & 71.65 & 0.67 & 0.08 & 25.6 & $<0.001$ \\
\hline \multirow[t]{2}{*}{ Headache } & A & 66 & 3.01 & 0.63 & 2.37 & 78.89 & 0.57 & 0.07 & 33.5 & $<0.001$ \\
\hline & B & 60 & 3.01 & 0.88 & 2.13 & 70.71 & 0.56 & 0.07 & 29.1 & $<0.001$ \\
\hline \multirow[t]{2}{*}{ Heaviness } & $\mathbf{A}$ & 66 & 2.90 & 0.57 & 2.33 & 80.2 & 0.47 & 0.05 & 39.9 & $<0.001$ \\
\hline & $\mathbf{B}$ & 60 & 2.65 & 0.48 & 2.16 & 81.76 & 0.58 & 0.07 & 28.5 & $<0.001$ \\
\hline \multirow[t]{2}{*}{ DFA } & $\mathbf{A}$ & 66 & 3.27 & 0.81 & 2.43 & 74.53 & 0.55 & 0.06 & 37.5 & $<0.001$ \\
\hline & $\mathbf{B}$ & 60 & 3.25 & 0.61 & 2.63 & 81.02 & 0.58 & 0.07 & 35.0 & $<0.001$ \\
\hline \multirow[t]{2}{*}{ DSA } & $\mathbf{A}$ & 66 & 3.22 & 0.80 & 2.42 & 75.11 & 0.55 & 0.06 & 35.3 & $<0.001$ \\
\hline & B & 60 & 3.21 & 0.78 & 2.43 & 75.64 & 0.56 & 0.07 & 33.4 & $<0.001$ \\
\hline \multirow[t]{2}{*}{ PWE } & $\mathbf{A}$ & 66 & 2.98 & 0.62 & 2.36 & 79.18 & 0.54 & 0.06 & 35.2 & $<0.001$ \\
\hline & B & 60 & 3.25 & 0.98 & 2.26 & 69.74 & 0.54 & 0.07 & 32.02 & $<0.001$ \\
\hline \multirow{2}{*}{$\begin{array}{l}\text { C.S (satisfied/ } \\
\text { dissatisfied) }\end{array}$} & $\mathbf{A}$ & 66 & 2.78 & 0.69 & 2.09 & 75.0 & 0.38 & 0.04 & 44.5 & $<0.001$ \\
\hline & B & 60 & 2.65 & 0.78 & 1.85 & 69.81 & 0.48 & 0.06 & 28.7 & $<0.001$ \\
\hline \multirow[t]{2}{*}{ IQL } & A & 66 & 2.95 & 0.69 & 2.27 & 76.9 & 0.54 & 0.06 & 36.2 & $<0.001$ \\
\hline & B & 60 & 2.98 & 0.73 & 2.25 & 75.41 & 0.43 & 0.05 & 39.9 & $<0.001$ \\
\hline \multirow{2}{*}{$\begin{array}{l}\text { C.S (worried/ } \\
\text { distressed) }\end{array}$} & A & 66 & 2.87 & 0.63 & 2.24 & 77.89 & 0.43 & 0.05 & 42.1 & $<0.001$ \\
\hline & B & 60 & 2.76 & 0.53 & 2.23 & 80.72 & 0.49 & 0.06 & 34.6 & $<0.001$ \\
\hline \multirow[t]{2}{*}{ IDF } & A & 66 & 2.83 & 0.59 & 2.24 & 79.14 & 0.43 & 0.05 & 42.18 & $<0.001$ \\
\hline & B & 60 & 2.7 & 0.58 & 2.11 & 78.39 & 0.37 & 0.04 & 44.02 & $<0.001$ \\
\hline
\end{tabular}

*(DFA (Difficulty in falling asleep), DSA (Difficulty in staying asleep), PWE (Problem in waking up too early), C.S (Current Sleep (satisfied/ dissatisfied)), IQL (Impairment in Quality of Life), C.S (Current sleep (worried/ distressed ), IDF (Interference in daily function), Before treatment (BT), After treatment (AT), After follow up (AFU), Differential item functioning (DIF), Standard deviation (SD).) 
Int. J. Ayur. Pharma Research, 2021;9(12):1-10

Table 5: Intra group Comparison between Group A and Group B after follow up

\begin{tabular}{|c|c|c|c|c|c|c|c|c|c|c|}
\hline \multirow[t]{2}{*}{ Parameters } & \multirow[t]{2}{*}{ Group } & \multirow[t]{2}{*}{$\mathbf{N}$} & \multicolumn{3}{|c|}{ Mean } & \multirow{2}{*}{$\begin{array}{c}\text { \% of } \\
\text { Relief }\end{array}$} & \multirow{2}{*}{$\begin{array}{l}\text { SD } \\
( \pm)\end{array}$} & \multirow{2}{*}{$\begin{array}{l}\text { SE } \\
( \pm)\end{array}$} & \multirow[t]{2}{*}{$\mathbf{T}$} & \multirow[t]{2}{*}{$\mathbf{P}$} \\
\hline & & & BT & AT & DIF & & & & & \\
\hline \multirow[t]{2}{*}{ Sleeplessness } & $\mathbf{A}$ & 66 & 3.12 & 0.83 & 2.28 & 73.30 & 0.45 & 0.05 & 40.7 & $<0.001$ \\
\hline & B & 60 & 3.11 & 0.81 & 2.3 & 73.79 & 0.53 & 0.06 & 33.5 & $<0.001$ \\
\hline \multirow[t]{2}{*}{ Headache } & $\mathbf{A}$ & 66 & 3.01 & 0.72 & 2.28 & 75.89 & 0.48 & 0.06 & 38.02 & $<0.001$ \\
\hline & B & 60 & 3.01 & 0.81 & 2.2 & 72.29 & 0.54 & 0.07 & 31.2 & $<0.001$ \\
\hline \multirow[t]{2}{*}{ Heaviness } & $A$ & 66 & 2.90 & 0.57 & 2.33 & 80.2 & 0.47 & 0.05 & 39.9 & $<0.001$ \\
\hline & B & 60 & 2.65 & 0.43 & 2.21 & 83.64 & 0.49 & 0.06 & 35.0 & $<0.001$ \\
\hline \multirow[t]{2}{*}{ DFA } & $\mathbf{A}$ & 66 & 3.27 & 0.98 & 2.28 & 69.9 & 0.45 & 0.05 & 40.7 & $<0.001$ \\
\hline & B & 60 & 3.25 & 0.75 & 2.5 & 76.92 & 0.53 & 0.06 & 36.07 & $<0.001$ \\
\hline \multirow[t]{2}{*}{ DSA } & A & 66 & 3.22 & 0.92 & 2.30 & 71.36 & 0.49 & 0.06 & 37.7 & $<0.001$ \\
\hline & B & 60 & 3.21 & 0.86 & 2.35 & 73.05 & 0.48 & 0.03 & 37.8 & $<0.001$ \\
\hline \multirow[t]{2}{*}{ PWE } & A & 66 & 2.98 & 0.65 & 2.33 & 78.17 & 0.53 & 0.06 & 35.3 & $<0.001$ \\
\hline & B & 60 & 3.25 & 0.95 & 2.3 & 70.76 & 0.53 & 0.06 & 33.5 & $<0.001$ \\
\hline \multirow{2}{*}{$\begin{array}{l}\text { C.S (satisfied/ } \\
\text { dissatisfied) }\end{array}$} & A & 66 & 2.78 & 0.75 & 2.03 & 72.8 & 0.46 & 0.05 & 35.6 & $<0.001$ \\
\hline & B & 60 & 2.65 & 0.8 & 1.85 & 69.81 & 0.48 & 0.06 & 29.7 & $<0.001$ \\
\hline \multirow[t]{2}{*}{ IQL } & A & 66 & 2.95 & 0.71 & 2.24 & 75.89 & 0.46 & 0.05 & 39.08 & $<0.001$ \\
\hline & B & 60 & 2.98 & 0.8 & 2.18 & 73.18 & 0.43 & 0.05 & 39.19 & $<0.001$ \\
\hline \multirow{2}{*}{$\begin{array}{l}\text { C.S (worried/ } \\
\text { distressed) }\end{array}$} & A & 66 & 2.87 & 0.62 & 2.25 & 78.42 & 0.44 & 0.05 & 41.62 & $<0.001$ \\
\hline & B & 60 & 2.76 & 0.61 & 2.15 & 77.71 & 0.51 & 0.06 & 32.3 & $<0.001$ \\
\hline \multirow[t]{2}{*}{ IDF } & $\mathbf{A}$ & 66 & 2.83 & 0.57 & 2.25 & 79.67 & 0.44 & 0.05 & 41.62 & $<0.001$ \\
\hline & B & 60 & 2.7 & 0.66 & 2.03 & 75.3 & 0.41 & 0.05 & 38.3 & $<0.001$ \\
\hline
\end{tabular}

\section{Intra group comparison}

After treatment and after follow up Bala and Shatavari Siddha Ksheera Shirodhara and Tila oil Shirodhara was highly significant $(\mathrm{P}<0.001)$ on the above mentioned symptoms.

Table 6: Inter-group comparison in Group A and Group B (AT and After follow up)

\begin{tabular}{|c|c|c|c|c|c|c|c|c|}
\hline Parameters & Group & $\mathbf{N}$ & Mean & Variance & DF & $\mathbf{T}$ & $\mathbf{P}$ & Result \\
\hline \multirow[t]{2}{*}{ Sleeplessness } & A & 66 & 0.833 & 0.202 & \multirow[t]{2}{*}{124} & \multirow[t]{2}{*}{0.17} & \multirow[t]{2}{*}{0.8} & \multirow[t]{2}{*}{ NS } \\
\hline & B & 60 & 0.816 & 0.355 & & & & \\
\hline \multirow[t]{2}{*}{ Headache } & A & 66 & 0.727 & 0.478 & 124 & 0.64 & 0.5 & NS \\
\hline & B & 60 & 0.816 & 0.728 & & & & \\
\hline \multirow[t]{2}{*}{ Heaviness } & $\mathbf{A}$ & 66 & 0.575 & 0.278 & 124 & 1.39 & 0.1 & NS \\
\hline & B & 60 & 0.433 & 0.385 & & & & \\
\hline \multirow[t]{2}{*}{ DFA } & A & 66 & 0.984 & 0.138 & 124 & 2.86 & 0.5 & NS \\
\hline & B & 60 & 0.75 & 0.292 & & & & \\
\hline \multirow[t]{2}{*}{ DSA } & $\mathbf{A}$ & 66 & 0.924 & 0.286 & 124 & 0.55 & 0.5 & NS \\
\hline & B & 60 & 0.866 & 0.388 & & & & \\
\hline \multirow[t]{2}{*}{ PWE } & $\mathbf{A}$ & 66 & 0.651 & 0.353 & 124 & 2.49 & 0.01 & $S$ \\
\hline & B & 60 & 0.95 & 0.556 & & & & \\
\hline \multirow{2}{*}{$\begin{array}{l}\text { C.S (satisfied/ } \\
\text { dissatisfied) }\end{array}$} & A & 66 & 0.757 & 0.278 & 124 & 0.45 & 0.6 & NS \\
\hline & $\mathbf{B}$ & 60 & 0.8 & 0.26 & & & & \\
\hline \multirow[t]{2}{*}{ IQL } & $\mathbf{A}$ & 66 & 0.71 & 0.30 & 124 & 0.925 & 0.3 & NS \\
\hline & B & 60 & 0.8 & 0.26 & & & & \\
\hline \multirow{2}{*}{$\begin{array}{l}\text { C.S (worried/ } \\
\text { distressed) }\end{array}$} & $\mathbf{A}$ & 66 & 0.621 & 0.269 & 124 & 0.04 & 0.9 & NS \\
\hline & B & 60 & 0.616 & 0.308 & & & & \\
\hline \multirow[t]{2}{*}{ IDF } & A & 66 & 0.57 & 0.27 & 124 & 0.95 & 0.3 & NS \\
\hline & B & 60 & 0.66 & 0.29 & & & & \\
\hline
\end{tabular}

S: Significant, NS: Not Significant 


\section{Intergroup Comparison}

From the table no.6 it was found that there was statistically significant difference $(\mathrm{P}<0.01)$ in the symptom Problem in waking up early. There was no statistically difference found in the rest of the symptoms.

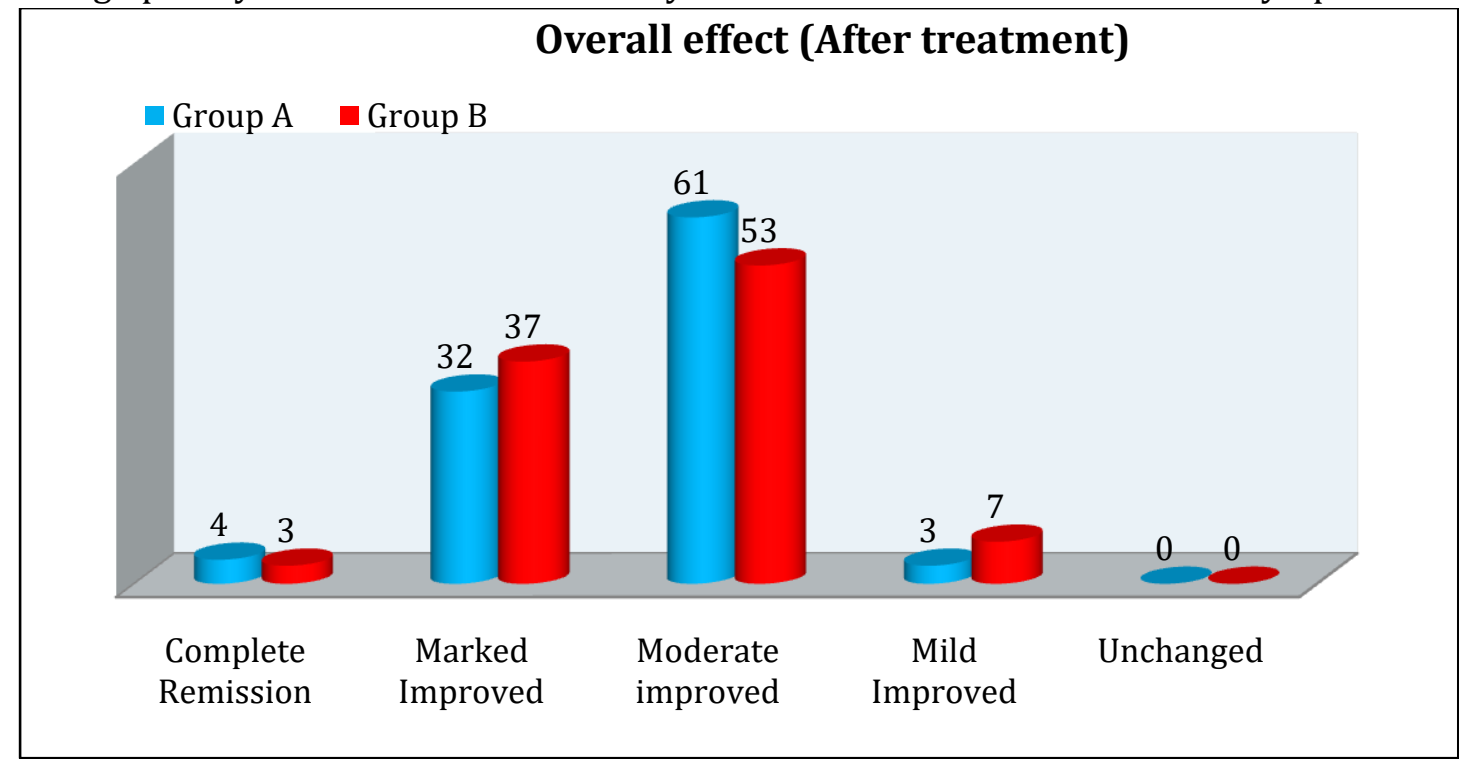

Table 7: Overall effect of therapy in both the groups after treatment

\begin{tabular}{|l|c|c|}
\hline Overall effect & Group A (in \%) & Group B (in \%) \\
\hline Complete Remission & 04 & 03 \\
\hline Marked improved & 32 & 37 \\
\hline Moderate Improved & 61 & 53 \\
\hline Mild improved & 03 & 07 \\
\hline Unchanged & 00 & 00 \\
\hline Total & 100 & 100 \\
\hline
\end{tabular}

Figure No.1: After treatment in Bala and Shatavari siddha Ksheeradhara group A 3\% patients were having mild improvement, in $61 \%$ there was moderate improvement, in $32 \%$ patients there were marked improvement and in 4\% patients there were complete remission. Whereas in Tila Taila Shirodhara Group 7\% patients were having mild improvement, in 53\% patients were having moderate improvement, in 37\% there was marked improvement and in $3 \%$ there was complete remission.

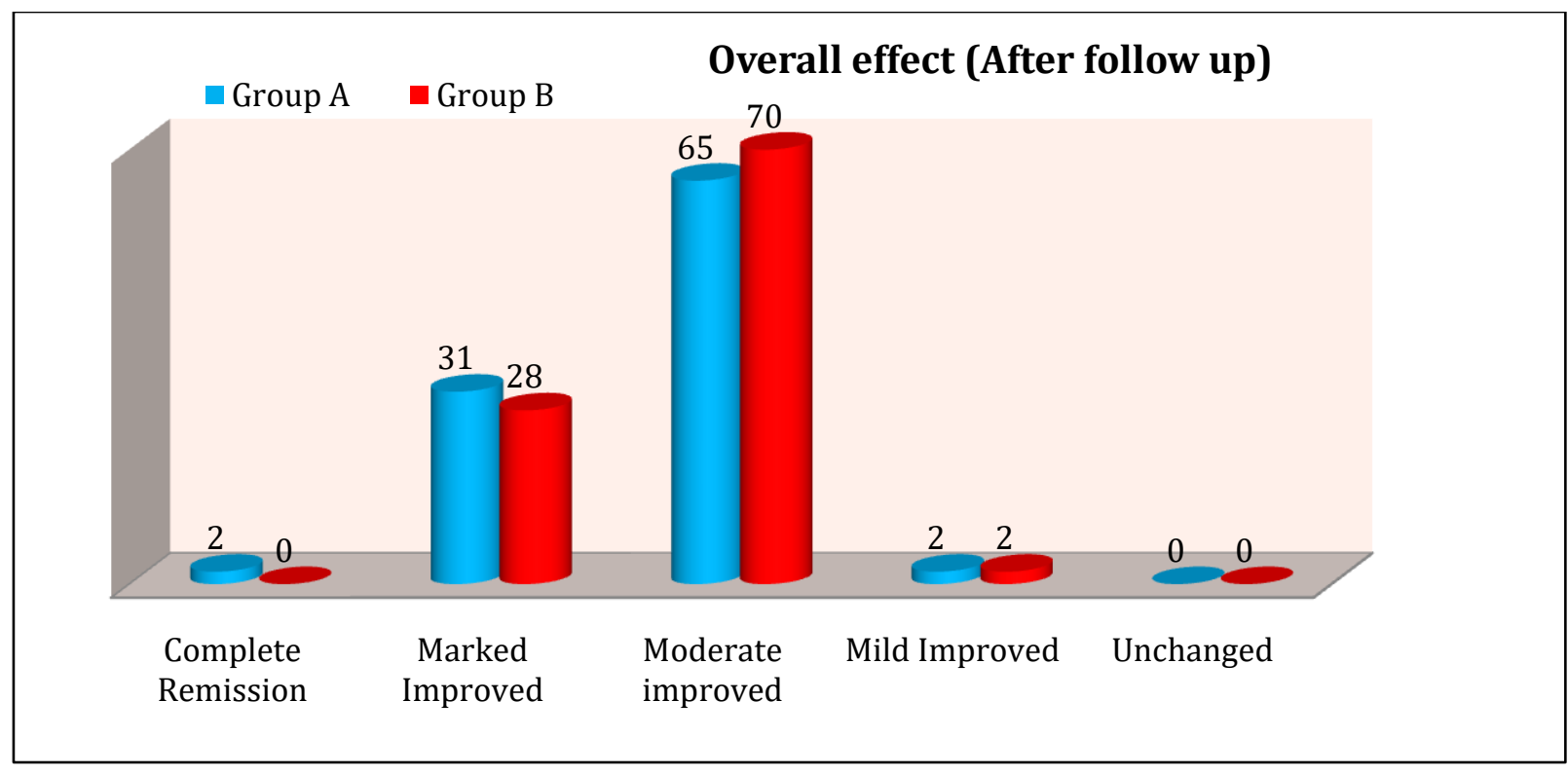


Int. J. Ayur. Pharma Research, 2021;9(12):1-10

Table 8: Overall effect of therapy in both the groups after follow up

\begin{tabular}{|l|c|c|}
\hline Overall effect & Group A (in \%) & Group B (in \%) \\
\hline Complete Remission & 02 & 00 \\
\hline Marked improvement & 31 & 28 \\
\hline Moderate Improved & 65 & 70 \\
\hline Mild improved & 02 & 02 \\
\hline Unchanged & 00 & 00 \\
\hline Total & 100 & 100 \\
\hline
\end{tabular}

Figure No.2: After follow up it was found that in group A in 2\% patients there were mild improvement, in $65 \%$ patients there were moderate improvement, in 31\% marked improvement was observed and in $2 \%$ patients there were complete remission Likewise in group B there was $2 \%$ patients in which mild improvement was seen. In $70 \%$ patients there were moderate improvement, in 28\% patients marked improvement was observed.

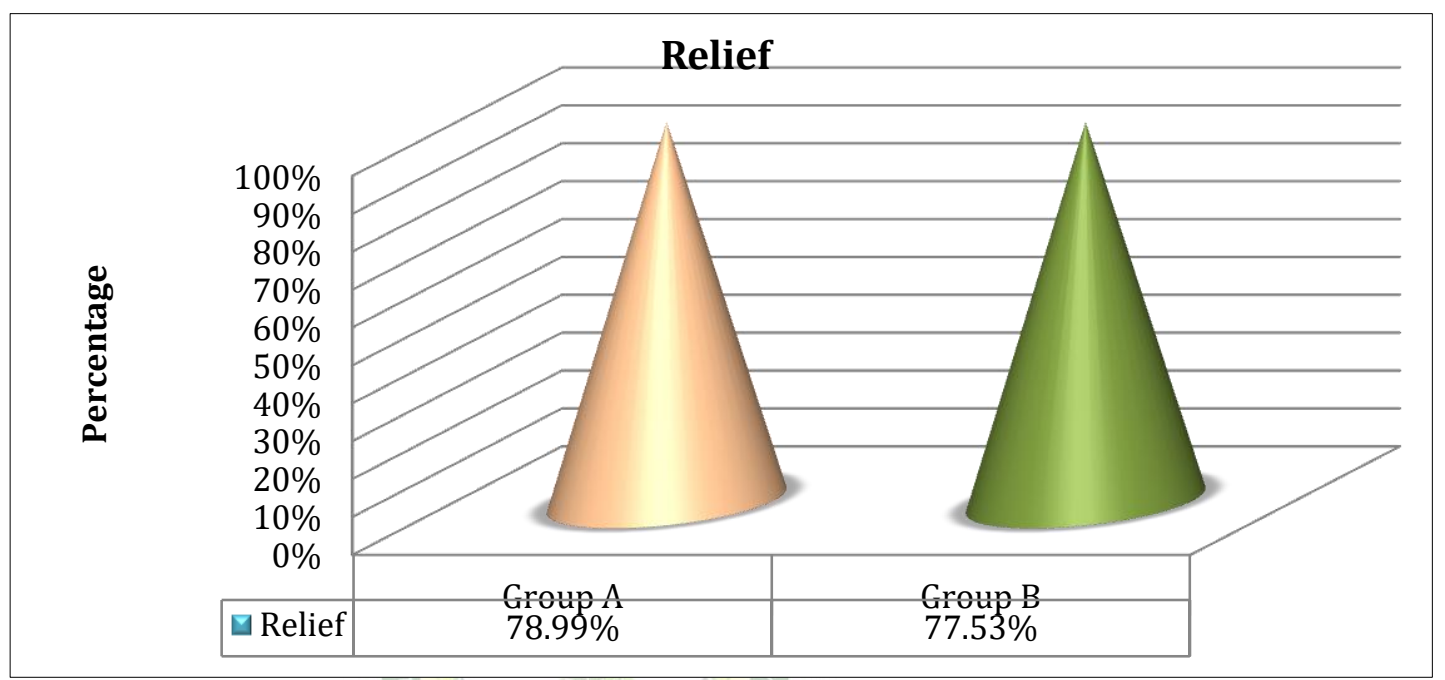

Figure No.3: After treatment relief in group A was 78.99\% and in Group B was 77.53\%.

Table 9: Comparison of overall relives obtained in both groups after treatment

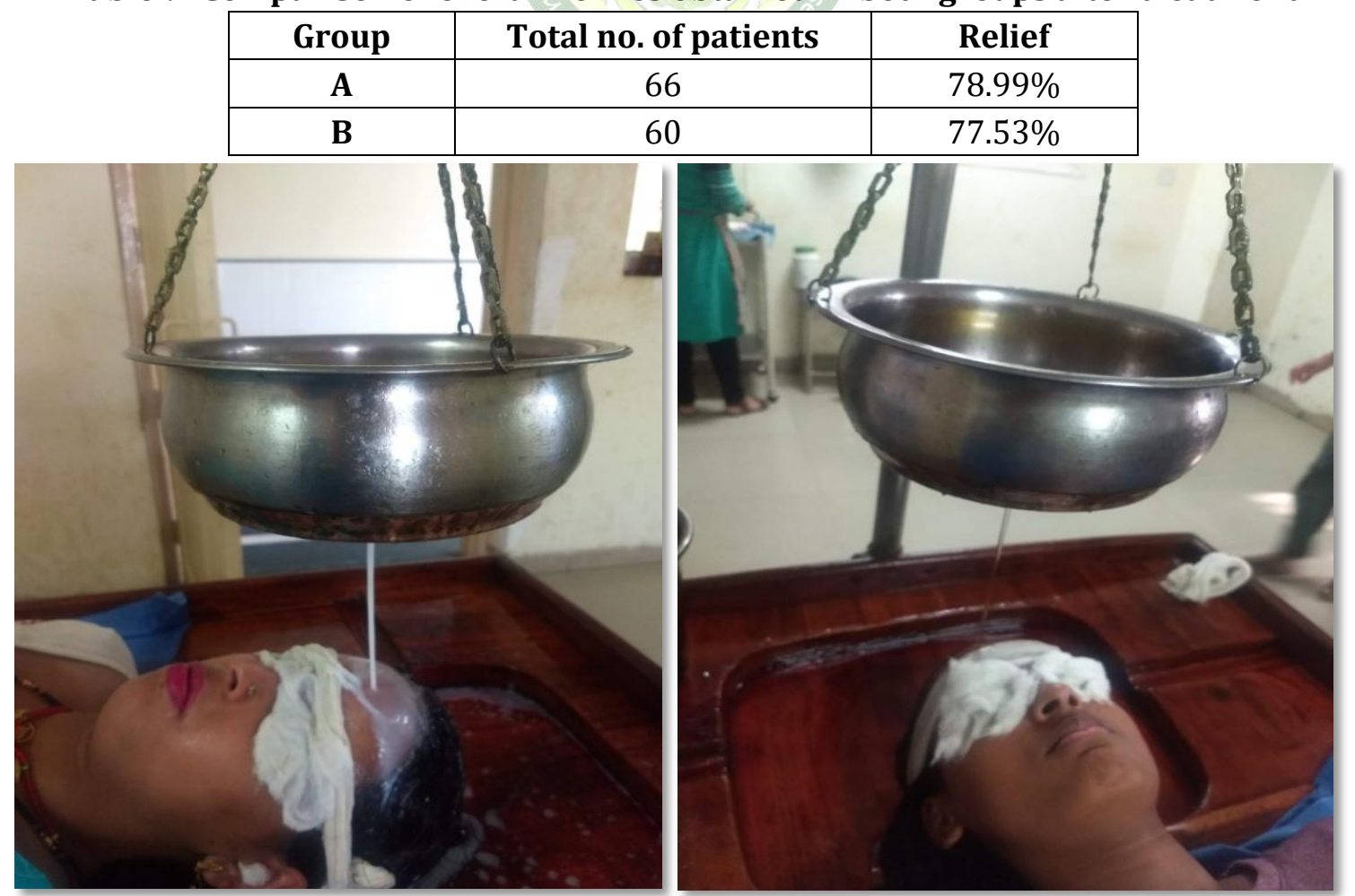

Figure no.4: (A-Bala and Shatavari siddha ksheera shirodhara B-Tila taila shirodhara) 


\section{Mode of action of Herbs}

In Group A the drugs used were Bala, Shatavri and Milk. Bala is mentioned as Balya and vatahara in Agrya dravya[13]. It possess Madhura rasa, Snighdha guna and Sheeta virya along with Balya and Vrishya properties due to which it pacifies Vata-pitta dosha[14]. Through various researches it was found that bala possess antioxidant properties and it has been proven as adaptogenic and immunomodulator[15,16]. Whereas Shatavari is having Madhura-tikta rasa, Madhura vipak and Sheeta virya along with this it is mentioned as Balya, Medhya and Rasayan with Vata and Pitta shamak properties[17]. In this trial Ksheera has been taken which is having Nidrajanna effect along with this it possess Snigdha, Guru, Sthira guna and Rasayan properties as well its helps in Manah prasadan effect and helpful in inducing sleep ${ }^{[18]}$. The drug used in Group B is Tila oil which possesses Kashaya, Madhura, Tikta and Katurasa, along with this Snigdha, Ushna and Guru guna also it is Balya medhya and Agni vardhak and pacify vata Dosha[19]. In pathology of Anidra mainly vitiated Dhatu is Vata- pitta and Rasadhatu. So, in this group all the three drugs used in Shirodhara helps in Rasadhatuposhana and Vardhan due to the Balya, Rasayan, Dhatupushti karma properties possessed by them. So, in Group A the effect was more as compared to Group B.

\section{Probable mode of action of Shirodhara}

It was found that overall relief was more in Bala and Shatavari Sidhha Ksheera Group as compared to Tila oil group. However both groups were found to be highly significant. Means both groups i.e., Bala and Shatavari Ksheera shirodhara and Tila oil Shirodhara were equally effective in the treatment of Anidra. This can be understood in these ways:

Shirodhara's mechanism can be deduced at the following levels:

The consequence of impulse generation.

1. Temperature's Impact

2. Absorption via the scalp

3. During the procedure, the dim light has an effect.

1. Effect of Impulse Generation- In Shirodhara therapy, a continuous stream of liquid is poured over the forehead, creating a steady pressure. Through the hollow sinus, this constant pressure amplifies and creates impulses, which are then sent within via cerebrospinal fluid[20]. This impulse activates sleepregulating parts of the brain, causing Melatonin, GABA, and Serotonin levels to normalize, as well as a drop in Histamine, Acetylcholine, and Dopamine levels. The temperature of the liquid poured over the forehead in this therapy is usually higher than the temperature of the body. According to one study, a slight local increase in temperature causes neuronal activity, which is linked to sleep patterns, and suppressing this causes awake. Mild skin warming has also been linked to sleep-like activity in the cerebral cortex and the reticular formation of the midbrain [21].

2. Absorption through the scalp vein- Drugs are absorbed through the scalp vein after being poured locally for 30-45 minutes in Shirodhara. Drugs enter the systemic circulatory system through emissary veins in the scalp ${ }^{[22]}$. One study in Japan found that drug delivery through the scalp is a viable route for drug administration. Shirodhara may thus aid in achieving the desired results [23].

3. Shirodhara therapy is performed under dark light, which has an effect on the procedure. The explanation for this could be that melatonin hormone is released more under dim light, which aids in sleep initiation [24]. As a result, this therapy must be performed in a suitable environment.

\section{CONCLUSION}

Anidra is a Vata nanatmaj vikara with main Dosha involved are Vata and Pitta. Bala and Shatavari Ksheera Shirodhara was more effective than Tila taila shirodhara as it contains Madhura- Tikta rasa, Guru, Snigdha guna, Sheeta virya and Madhura vipaka along with this it possess chemical constituent having antioxidant, immunomodulator and adaptogenic properties. In this study both groups were equally effective. So, it can be concluded that procedural effect may have main role as compared to drug. Also it can be concluded that Anidra can be best treated by Shirodhara which is anon pharmacological intervention and can reduce the chances of adverse effect caused by pharmacological drugs like sedatives and hypnotics.

\section{REFERENCES}

1. Tarakvachaspati T. Vachaspataym. Reprint.Vol.1. Delhi.Rashtriya Sanskrit Sansthan, 2006. p.162

2. Trikamji Y. Editor. Charak Samhita Ayurveda dipika. First edition. Varansi, Chaukhambha surbhati pratishathan, 2006 p.no.74

3. Trikamji Y. Editor. Sushrutasamhita with Nibandh sangrah First edition, Varanasi, Chaukhambha sankritsantahan 2012 p.358

4. MitraJ. Editor. Ashtanga Sangrahshashilekha Fourth edition, Varanasi, Chaukhamba krishnadas academy. 2016 p.93

5. Trikamji Y. Editor. Charak Samhita Ayurveda dipika. First edition. Varanasi, Chaukhambha surbhati pratishathan, 2006 p.50

6. Samhita P, TalyArun B,Sinha S, Gururaj G, Girish N, NagarajaD. Prevalence of Insomnia. [internet] SleepRelated Disorders Sleep-Related Disorders among a Healthy Population in South India, 2012 Mar7 [cited 
2018 Apr12].60(1);68-74 Available from, www. neurologyindia.com/article.

7. An Overview of Insomnia [Internet]. WebMD. WebMD; [cited 2018Apr17]. Available from: https://www.webmd.com/sleep-disorders/ guide/ insomnia-symptoms-and-causes\#1

8. Bansode R.M. Nagdevte S.R. Role of shirodhara in management of anidra (Insomnia). A case study. International journal of Ayurveda and alternative medicine. [Internet].2016.4(5):246-248.

9. Kryger.roth.dement. Principles and Practice of Sleep Medicine Chapter.83, Diagnosis, Assessment and Evalution, P.no.791. 6th ed., ser. 0323317521, Elsevier Publication, 2015.

10. Pandey GS. Editor. Chunekar K.C. Commentator. Bhavaprakash nighantu of Bhavamishra, Edition revised Varanasi, Chaukhamba Bharati Academy, 2010, P. 351.

11. Ankad G, Bhagwat S, Hegde H, Subramanya M, Upadhya V, Pai S. Total polyphenolic contents and in vitro antioxidant properties of eight Sida species from Western Ghats, India. Journal of Ayurveda and Integrative Medicine [Internet]. 2015;6(1):24. Available from: https://www.ncbi.nlm.nih.gov/ pmc/articles/PMC4395924.

12. Sumanth M, Mustafa S. Antistress, adoptogenic activity of Sida cordifoliaroots in mice. Indian Journal of Pharmaceutical Sciences [Internet]. 2009;71(3):323. Available from: https://www.ncbi. nlm.nih.gov/pmc/articles/PMC2865797

13. Trikamji Y. Editor. Charak Samhita Ayurveda dipika. First edition. Varanasi, Chaukhambha surbhati pratishathan, 2006 p.284.

14. Sharma PV\& Sharma GP.Kaiydev nighantu. Edition reprint. Varanasi, Chaukhambha orientalia; 2009.p. 165.

15. Ankad G, Bhagwat S, Hegde H, Subramanya M, Upadhya V, Pai S. Total polyphenolic contents and in vitro antioxidant properties of eight Sida species from Western Ghats, India. Journal of Ayurveda and Integrative Medicine [Internet]. 2015;6(1):24.
Available from: https://www.ncbi.nlm.nih.gov/ pmc/ articles/PMC4395924

16. Sumanth M, Mustafa S. Antistress, adoptogenic activity of Sida cordifoliaroots in mice. Indian Journal of Pharmaceutical Sciences [Internet]. 2009;71(3):323. Available from: https://www.ncbi. nlm.nih.gov/pmc/articles/PMC2865797

17. Pandey GS.Editor. Chunekar K.C. Commentator. Bhavaprakash nighantu of Bhavamishra, Edition revised Varanasi, Chaukhamba Bharati Academy, 2010, P. 378.

18. Trikamji Y. Editor. Charak Samhita Ayurveda dipika. First edition.Varanasi, Chaukhambha surbhati pratishathan, 2006 p.34.

19. Pandey GS.Editor. Chunekar K.C. Commentator. Bhavaprakash nighantu of Bhavamishra, Edition revised Varanasi, Chaukhamba Bharati Academy, 2010, P. 639.

20. Kajaria D, tripathi J, tiwari S. An Appraisal of The Mechanism of Action of Shirodhara. Annals of Ayurvedic Medicine. 2013;2:114-117.

21. Romeijn N, Raymann R, Møst E, Te Lindert B, Van Der Meijden W, Fronczek R et al. Sleep, vigilance, and thermosensitivity. Pflügers Archiv - European Journal of Physiology. 2011;463(1):169-176.

22. Chaurasia BD, human anatomy vol.3,edited by krishna garg, chapter1, Osteology of head and neck, New Delhi, CBS publishers and distributors pvt ltd, 2010, p.18

23. Ogiso T, Shiraki T, Okajima K, Tanino T, Iwaki $M$, Wada T. Transfollicular Drug Delivery: Penetration of Drugs Through Human Scalp Skin and Comparison of Penetration Between Scalp and Abdominal Skins In Vitro. Journal of Drug Targeting. 2002; 10(5):369-378.

24. Gooley J, Chamberlain K, Smith K, Khalsa S, Rajaratnam S, Van Reen E et al. Exposure to Room Light before Bedtime Suppresses Melatonin Onset and Shortens Melatonin Duration in Humans. The Journal of Clinical Endocrinology \& Metabolism. 2011;96(3):E463-E472.

\section{Cite this article as:}

Rani Pooja, Wetal.R.Vishakha, Gupta Arun. A Comparative Study to Evaluate the Effect of Bala and Shatavari Siddha Ksheera Shirodhara and Tila Taila Shirodhara in Anidra (Insomnia). International Journal of Ayurveda and Pharma Research. 2021;9(12):1-10.

https://doi.org/10.47070/ijapr.v9i12.2205

Source of support: Nil, Conflict of interest: None Declared

\section{*Address for correspondence} Dr. Rani Pooja,

Panchakarma Vaidya,

All India Institute of Ayurveda, Gautam Puri, Sarita Viahar, New Delhi.

Email: pathakpooja773@gmail.com

Disclaimer: IJAPR is solely owned by Mahadev Publications - dedicated to publish quality research, while every effort has been taken to verify the accuracy of the content published in our Journal. IJAPR cannot accept any responsibility or liability for the articles content which are published. The views expressed in articles by our contributing authors are not necessarily those of IJAPR editor or editorial board members. 